\title{
Economic performance of production systems with crop-livestock integration in no-tillage systems
}

\author{
Henrique Pereira dos Santos ${ }^{1} \oplus$, Renato Serena Fontaneli ${ }^{1,2}{ }^{\circledR}$, Genei Antonio Dalmago ${ }^{1} \odot$, \\ Ricardo Lima de Castro ${ }^{1} \odot$, Anderson Santi ${ }^{1}$, Taynara Possebom² ${ }^{\circledR}$

\footnotetext{
1'Embrapa Trigo, Rodovia BR 285, Km 294, CEP 99001-970, Passo Fundo, RS, Brasil. E-mail: henrique.santos@embrapa.br; renato.fontaneli@cnpt.embrapa.br; genei.dalmago@embrapa.br; ricardo.castro@embrapa.br; anderson.sant@embrapa.br

${ }^{2}$ Universidade de Passo Fundo, Faculdade de Agronomia e Medicina Veterinária, Campus I, São José, CEP 99001-970, Passo Fundo, RS, Brasil. E-mail: thay-possebom@hotmail.com
}

ABSTRACT: Adopting wheat that has additional aptitudes to the only function of grain production in crop-livestock integration systems may be an economical alternative for better using the vast expanse of farmland during the autumn-winter period in southern Brazil. The objective of this study was to evaluate economically the crop-livestock integration (CLI) system, in comparison to systems of grain production only. The treatments consisted of six CLI systems, containing either annual winter pasture, soil cover or dualpurpose cereals: system I (wheat/soybean and vetch/maize); system II (wheat/soybean and black oat/maize pasture); system III (wheat/soybean and black oat/soybean pasture); system IV (wheat/soybean and pea/maize); system V (wheat/soybean, dualpurpose triticale/soybean and vetch/soybean); and system VI (wheat/soybean, dual-purpose white oat/soy and dual-purpose wheat/ soybean). The treatments were repeated four times in the randomized block design. Calculation of the operational cost and net return of the production systems followed the technical coefficient matrix of the experiment and the prices of inputs and machines from the cultivation year, based on the 2016 market . Systems II and III, which had annual winter pastures, were more profitable than systems I and IV, with legume cover cropping. System VI, with white oat and double-purpose wheat, demonstrated a higher economic return when compared to the system V, with triticale. Overall, system II stood out due to its higher net return.

\section{Desempenho econômico de sistemas de produção com integração lavoura-pecuária em sistema plantio direto}

RESUMO: A adoção de trigos que possuem aptidões adicionais à função única de produção de grãos, em sistemas de integração lavoura-pecuária (ILP) pode ser uma alternativa econômica para melhor uso da vasta extensão de terras agrícolas durante o período de outono-inverno no sul do Brasil. $\mathrm{O}$ objetivo deste trabalho foi avaliar economicamente o sistema ILP, em comparação com sistemas somente de produção de grãos. Os tratamentos consistiram em seis sistemas de ILP, com pastagem anual de inverno, ou cobertura de solo ou cereais de duplo propósito: sistema I (trigo/soja e ervilhaca/milho); sistema II (trigo/soja e pastagem de aveia preta/milho); sistema III (trigo/soja e pastagem de aveia preta/soja); sistema IV (trigo/soja e ervilha/milho); sistema V (trigo/soja, triticale de duplo propósito/soja e ervilhaca/soja); e sistema VI (trigo/soja, aveia branca de duplo propósito/soja e trigo de duplo propósito/soja). Tratamentos foram repetidos quatro vezes no delineamento em blocos ao acaso. $O$ cálculo do custo operacional e da receita líquida dos sistemas de produção foi elaborado a partir da matriz de coeficientes técnicos do experimento e dos preços de insumos e máquinas do ano de cultivo se basearam no mercado de 2016. Os sistemas II e III que continham pastagem anual de inverno foram os mais lucrativos, comparados aos sistemas I e IV, que continham leguminosas de cobertura de solo. O sistema $\mathrm{VI}$, com aveia branca e trigo de duplo propósito apresentou maior retorno econômico, em relação ao sistema V, com triticale. No geral, o destaque foi o sistema II pela maior receita líquida. 


\section{Introduction}

Long-term experiments involving the grain production systems have been developed at Embrapa Trigo since the 1980s (Santos et al., 2015a). Many of these studies were held in order to estimate the agricultural crop effect. For such, all species from each system, both in winter (white oat, black oat, vetch and wheat) and in summer (maize, soybeans and sorghum) should be sown every year.

From the 1990s onwards, a new series of long-term experiments began, involving grain crops (white oat, maize, soybeans and wheat) in rotation with annual pastures of winter (black oat, ryegrass and vetch) and summer (millet), in addition to perennials composed by tall fescue (Festuca arundinacea Schred) or Pensacola bahia grass (Paspalum notatum Flugge) intercropped with white clover (Trilium repens L.), red clover (Trifolium pratense L.) and common bird's-foot trefoil (Lotus corniculatus L.) (Santos et al., 2015b; Fontaneli et al., 2016).

It is worth emphasizing that crop-livestock integration, composed by systems for producing grains and pastures, is an efficient alternative in terms of soil and pasture recovery, in addition to provide a greater production diversity, generating opportunities to increase the economic return over time (Balbino et al., 2011). Furthermore, the use of this technology is associated with an expected improvement in chemical, physical and biological properties of the soil, as well as the possibility of reducing the occurrence of pests, diseases and weeds (Vilela et al., 2011; Costa et al., 2015; Kunde et al., 2018, Bonetti et al., 2019).

However, in the economic return context, it is necessary to conduct studies focused on the long term, which consider the combination and succession of crops in a production system with crop-livestock integration. Within this scope, consolidated information can be obtained in long-term experiments, as these are essential when considering parameters characterized by slow temporal dynamics. It is notable that short-term experiments only focus on the initial trajectory, while long-term experiments describe the mechanisms involved in the temporal dynamics and in the variation of trajectories over time (Knapp et al., 2012).

Studies in this line should also consider that, although some crops have high grain yields, the higher economic return may be associated to those with lower grain yields if they are better remunerated (Fontaneli et al., 2000; Santos et at., 2003). Using soil cover cropping contributes in reducing the use of inputs and/or to improve the yield of the systems in which they are inserted to, acting as a necessary part for adequately complementing the production systems.

In the study region, there is a growing interest in using annual winter grasses and legumes, either alone or in mixtures. In this context, the use of oat, rye, ryegrass, vetch, wheat, triticale and clover has been standing out, both for soil cover cropping and grazing, with them also pointed out as possible alternatives when aiming to promote economic return for the rural producers (Fontaneli et al., 2016). This alternative is of fundamental importance because it provides an opportunity to produce food for cattle at a period of the year with a recognized forage shortage.

The integration of crops with annual winter pastures (black oat or black oat + vetch) or with dual-purpose cereals (white oat, rye, barley, wheat and triticale) has been successful because this agricultural practice also has been conducted in crop rotation under no-tillage system (Fontaneli et al., 2015). However, it is essential to establish the profitability of integrating crops with dairy or beef cattle breeding, in these same regions, as this activity requires grazing practically over all year. Moreover, the identification of the CLI system with the best economic performance, low risk and feasible adoption by the farmers, becomes a necessity.

Therefore, the use of CLI technology, understood as a productive process involving the activities of agriculture and livestock in consortium, crop succession or rotation, can generate additional profit by increasing the production and the income flow stability of the rural property, in addition to maximizing and distributing the use of labor during the year (De Mori et al., 2015; Reis et al., 2017). This technology can contribute to a greater herd productivity and provision of products of high protein value in the off-season, with reduced production costs and losses. Furthermore, this same system can collaborate in maintaining and improving the physical, chemical and biological characteristics of the soil, with positive effects on the yield of subsequent crops.

The objective of this study was to verify the economic performance of production systems with crop-livestock integration, in comparison with annual grain production systems, under the no-tillage system.

\section{Materials and Methods}

This study was conducted at Embrapa Trigo, in the

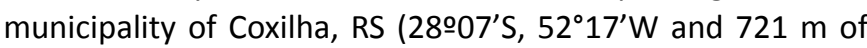
altitude), in a soil classified as an Oxisol or typical Dystrophic Red Latosol (Santos et al., 2018). The results presented in this study comprise the agricultural harvests from 2005/2006 to 2015/2016.

The treatments consisted in six grain-production systems in integration with annual winter pastures: system I [wheat (Triticum aestivum L.)/soybean (Glycine max (L.) Merrill) and vetch (Vicia sativa L.)/maize (Zea mays L.)]; system II [wheat/ soybean and black oat pasture (Avena swheatsa Schreb.)/ maize]; system III (wheat/soybean and black oat pasture/ soybean); system IV [wheat/soybean and pea (Pisum sativum L. subspecies arvense)/maize]; system $\mathrm{V}$ [(wheat/soybean, dual-purpose triticale ( $X$ Tricosecale Wittmack)/soybean and vetch/soybean)]; and system VI [wheat/soybean, dual-purpose white oat (Avena sativa L.)/soybean and dual-purpose wheat/ soybean] (Table 1). Summer and winter crops alike were all established under the no-tillage system.

Maintenance fertilization was performed according to the indication for each crop and based on the soil analysis results of the Soil Fertility and Chemistry Commission from RS/SC 
Table 1. Production systems involving grain crops and annual winter pastures, under the no-tillage system, harvests from 2005/2006 to 2015/2016.

\begin{tabular}{|c|c|c|c|c|c|c|c|c|c|c|c|}
\hline \multirow{2}{*}{$\begin{array}{l}\text { Production } \\
\text { system }\end{array}$} & \multicolumn{11}{|c|}{ Year } \\
\hline & 2005 & 2006 & 2007 & 2008 & 2009 & 2010 & 2011 & 2012 & 2013 & 2014 & 2015 \\
\hline \multirow{2}{*}{ System I } & $W / S$ & $\mathrm{~V} / \mathrm{M}$ & $W / s$ & $\mathrm{~V} / \mathrm{M}$ & $W / s$ & $\mathrm{~V} / \mathrm{M}$ & $w / s$ & $\mathrm{~V} / \mathrm{M}$ & $w / S$ & $\mathrm{~V} / \mathrm{M}$ & $w / s$ \\
\hline & $\mathrm{V} / \mathrm{M}$ & $W / s$ & $\mathrm{~V} / \mathrm{M}$ & W/s & $\mathrm{V} / \mathrm{M}$ & $W / S$ & $\mathrm{~V} / \mathrm{M}$ & $w / s$ & $\mathrm{~V} / \mathrm{M}$ & $W / s$ & $\mathrm{~V} / \mathrm{M}$ \\
\hline \multirow{2}{*}{ System II } & $\mathrm{W} / \mathrm{s}$ & $\mathrm{Bo} / \mathrm{M}$ & $\mathrm{W} / \mathrm{s}$ & $\mathrm{Bo} / \mathrm{M}$ & W/s & Bo/M & $\mathrm{W} / \mathrm{s}$ & $\mathrm{Bo} / \mathrm{M}$ & W/s & $\mathrm{Bo} / \mathrm{M}$ & $\mathrm{W} / \mathrm{s}$ \\
\hline & $\mathrm{Bo} / \mathrm{M}$ & $\mathrm{w} / \mathrm{s}$ & $\mathrm{Bo} / \mathrm{M}$ & w/s & $\mathrm{Bo} / \mathrm{M}$ & $W / s$ & $\mathrm{Bo} / \mathrm{M}$ & $w / s$ & $\mathrm{Bo} / \mathrm{M}$ & $\mathrm{W} / \mathrm{s}$ & $\mathrm{Bo} / \mathrm{M}$ \\
\hline \multirow{2}{*}{ System III } & $W / S$ & $\mathrm{Bo} / \mathrm{S}$ & W/s & Bo/S & W/s & $\mathrm{Bo} / \mathrm{S}$ & $W / S$ & $\mathrm{Bo} / \mathrm{S}$ & $W / s$ & $\mathrm{Bo} / \mathrm{S}$ & $\mathrm{W} / \mathrm{s}$ \\
\hline & $\mathrm{Bo} / \mathrm{S}$ & $W / s$ & $\mathrm{Bo} / \mathrm{S}$ & $w / s$ & $\mathrm{Bo} / \mathrm{S}$ & $W / s$ & $\mathrm{Bo} / \mathrm{s}$ & $w / s$ & $\mathrm{Bo} / \mathrm{S}$ & $W / S$ & $\mathrm{Bo} / \mathrm{s}$ \\
\hline \multirow{2}{*}{ System IV } & W/S & $\mathrm{P} / \mathrm{M}$ & W/S & $\mathrm{P} / \mathrm{M}$ & W/s & $\mathrm{P} / \mathrm{M}$ & W/S & $\mathrm{P} / \mathrm{M}$ & W/s & $\mathrm{P} / \mathrm{M}$ & $W / S$ \\
\hline & $\mathrm{P} / \mathrm{M}$ & $\mathrm{W} / \mathrm{s}$ & $P / M$ & $w / s$ & $P / M$ & $W / s$ & $P / M$ & W/s & $\mathrm{P} / \mathrm{M}$ & $\mathrm{W} / \mathrm{s}$ & $P / M$ \\
\hline \multirow{3}{*}{ System V } & $w / s$ & $\mathrm{Tl} / \mathrm{S}$ & $\mathrm{V} / \mathrm{S}$ & $\mathrm{W} / \mathrm{s}$ & $\mathrm{Tl} / \mathrm{S}$ & $\mathrm{V} / \mathrm{S}$ & $\mathrm{Tl} / \mathrm{S}$ & $\mathrm{Tl} / \mathrm{S}$ & $\mathrm{V} / \mathrm{S}$ & $\mathrm{W} / \mathrm{s}$ & $\mathrm{Tl} / \mathrm{S}$ \\
\hline & $\mathrm{Tl} / \mathrm{S}$ & $\mathrm{V} / \mathrm{S}$ & W/s & $\mathrm{Tl} / \mathrm{S}$ & $\mathrm{V} / \mathrm{S}$ & $W / S$ & $\mathrm{Tl} / \mathrm{S}$ & $\mathrm{V} / \mathrm{S}$ & $W / S$ & $\mathrm{Tl} / \mathrm{S}$ & V/S \\
\hline & $\mathrm{V} / \mathrm{S}$ & $w / s$ & $\mathrm{Tl} / \mathrm{S}$ & $\mathrm{V} / \mathrm{S}$ & $w / s$ & $\mathrm{Tl} / \mathrm{S}$ & $\mathrm{V} / \mathrm{S}$ & $w / s$ & $\mathrm{Tl} / \mathrm{S}$ & $\mathrm{V} / \mathrm{S}$ & $\mathrm{w} / \mathrm{s}$ \\
\hline \multirow{3}{*}{ System VI } & $\mathrm{W} / \mathrm{s}$ & Wo/s & $\mathrm{Wd} / \mathrm{s}$ & $\mathrm{W} / \mathrm{s}$ & Wo/s & $\mathrm{Wd} / \mathrm{s}$ & $w / s$ & Wo/s & $W d / S$ & $W / s$ & Wo/s \\
\hline & Wo/s & $\mathrm{Wd} / \mathrm{S}$ & $w / S$ & Wo/S & $\mathrm{Wd} / \mathrm{S}$ & $W / S$ & Wo/s & $\mathrm{Wd} / \mathrm{S}$ & W/S & Wo/S & $\mathrm{Wd} / \mathrm{S}$ \\
\hline & $\mathrm{Wd} / \mathrm{s}$ & $W / S$ & Wo/s & $\mathrm{Wd} / \mathrm{s}$ & $w / s$ & Wo/s & $\mathrm{Wd} / \mathrm{s}$ & $w / s$ & Wo/s & $\mathrm{Wd} / \mathrm{s}$ & $\mathrm{W} / \mathrm{s}$ \\
\hline
\end{tabular}

Wo: Dual-purpose white oat; Bo: black oat; V: vetch; P: pea; M: maize; S: soybean; W: wheat, Wd: dual-purpose wheat; and TI: dual-purpose triticale.

(Comissão de Química e Fertilidade do Solo - RS/SC, 2016). The soil samplings for determining the levels from nutrients and organic matter were taken annually in all plots after harvesting the summer crops.

Sowing time, weed control and phytosanitary treatments were all performed according to the indication for each crop, while the grain harvesting was with a thrasher adapted for plots. Maize was sown together with pea or vetch while still on a vegetative cycle, burned-down soon after with pre or post emergence herbicide. The plots were $20 \mathrm{~m}$ by $10 \mathrm{~m}$ (length $x$ width). Grain yield (white oat, maize, soybean, wheat and triticale) was determined by harvesting $1 / 3$ of the central area from each plot and adjusting the grain yield to $13 \%$ moisture. In pea and vetch, the dry matter yield was evaluated after cutting, and soon after the nitrogen accumulation $(\mathrm{N})$ of the dry matter was converted into urea.

The animal weight gain was estimated by the consumed dry matter from white oat, wheat and triticale (all of dualpurpose) and black oat. The considered conversion was 10 $\mathrm{kg}$ of dry forage consumed for $1 \mathrm{~kg}$ of live weight gain in the animals, for winter pastures (Fontaneli et al., 2016).

The experimental design was of randomized blocks, with four replicates. The net return evaluated the economic performance of the production systems in the six grainproduction systems with annual winter pasture (black oat), dual-purpose crops (white oat, wheat and triticale), cover crops (pea and vetch) and grain crops (maize, soybean and wheat). The understood concept of net return is the difference between gross income (yield from grain, dry matter of pea or vetch, converted into urea and animal weight gain multiplied by its selling price as a commercial product) and the total cost. The total cost is the sum of the variable costs (inputs + field operations costs) and the fixed cost (example: depreciation of facilities, machinery and equipment, and interest on the capital). The gross income was accounted through the average sales prices of the products with the mean from 2016, with the costs calculated from information obtained in November
2016, according to the data estimated for the production cost, the annual crop cycle, winter or summer, and each studied species (Conab, 2016) (Tables 2 and 3).

Table 2. Mean grain yield (GY), live weight gain (LWG), nitrogen (NY) and net return of winter and summer crops, harvests from $2005 / 2006$ to $2015 / 2016$, in production systems with crop-livestock integration.

\begin{tabular}{|c|c|c|c|c|}
\hline \multirow{2}{*}{$\begin{array}{c}\text { Production } \\
\text { system }\end{array}$} & \multirow{2}{*}{ Crop } & \multicolumn{2}{|c|}{ Yield (kg ha-1) } & \multirow{2}{*}{$\begin{array}{c}\text { Net return } \\
\text { (U\$/ha) }\end{array}$} \\
\hline & & Grains & LWG or $\mathbf{N}$ & \\
\hline \multirow{4}{*}{ System I } & Wheat (GY) & 2,340 & & 408.11 \\
\hline & Soybean (GY) & 2,776 & & 968.39 \\
\hline & Vetch (NY) & & 66 & 383.92 \\
\hline & Maize (GY) & 7,731 & & $1,119.79$ \\
\hline \multirow{4}{*}{ System II } & Wheat (GY) & 2,407 & & 419.79 \\
\hline & Soybean (GY) & 2,719 & & 948.32 \\
\hline & Black oat (LWG) & & 152 & 201.15 \\
\hline & Maize (GY) & 8,173 & & $1,183.81$ \\
\hline \multirow{4}{*}{ System III } & Wheat (GY) & 2,529 & & 441.07 \\
\hline & Soybean (GY) & 2,510 & & 875.56 \\
\hline & Black oat (LWG) & & 166 & 219.34 \\
\hline & Soybean (GY) & 2,591 & & 903.71 \\
\hline \multirow{4}{*}{ System IV } & Wheat (GY) & 2,365 & & 412.47 \\
\hline & Soybean (GY) & 2,789 & & 972.96 \\
\hline & Pea (NY) & & 49 & 387.40 \\
\hline & Maize (GY) & 7,459 & & $1,080.43$ \\
\hline \multirow{6}{*}{ System V } & Wheat (GY) & 2,570 & & 448.22 \\
\hline & Soybean (GY) & 2,635 & & 919.17 \\
\hline & Triticale (GY/LWG) & 1,222 & 92 & 626.28 \\
\hline & Soybean (GY) & 2,498 & & 871.37 \\
\hline & Vetch (NY) & & 92 & 383.92 \\
\hline & Soybean (GY) & 2,632 & & 918.23 \\
\hline \multirow{6}{*}{ System VI } & Wheat (GY) & 2,027 & & 353.52 \\
\hline & Soybean (GY) & 2,605 & & 908.69 \\
\hline & White oat (GY/LWG) & 623 & 92 & 461.20 \\
\hline & Soybean (GY) & 2,614 & & 911.75 \\
\hline & DpWheat (GY/LWG) & 1,609 & 119 & 626.28 \\
\hline & Soybean (GY) & 2,678 & & 934.00 \\
\hline
\end{tabular}

GPV: animal weight gain = consumption of $10 \mathrm{~kg}$ of MS from winter pasture $=1 \mathrm{~kg}$ of animal live weight.

Dollar exchange rate in 15/12/2016: U\$ 0.2956 (Source: Central Bank of Brazil, 2016). 
Table 3. Gross income and total costs/ha, from annual winter and summer crops, harvests from 2005/2016 to 2015/2016.

\begin{tabular}{|c|c|c|c|c|c|c|c|c|c|}
\hline & \multicolumn{9}{|c|}{ Crop } \\
\hline & Soybean & Maize & DpW & Wheat & Triticale & Vetch & Pea & Bo & Wo \\
\hline GY (kg ha-1) & 2,640 & 7,788 & 1,609 & 2,373 & 1,222 & & & & 623 \\
\hline LWG (kg ha-1) & & & 119 & & 92 & & & 159 & 92 \\
\hline NY (kg ha-1) & & & & & & 79 & 49 & & \\
\hline Gross income & 921.10 & $1,128.01$ & 626.28 & 413.86 & 626.28 & 33.63 & 110.08 & 210.25 & 461.20 \\
\hline Fertilization & 130.47 & 159.31 & 189.03 & 185.43 & 189.03 & 116.08 & 116.08 & 225.51 & 189.03 \\
\hline Herbicides & 20.44 & 41.47 & 89.09 & 37.63 & 37.63 & - & - & 2.07 & 2.07 \\
\hline Fungicides & 24.37 & - & 16.18 & 56.22 & 15.65 & - & - & - & 15.65 \\
\hline Insecticides & 29.24 & - & 21.78 & 39.55 & 21.78 & 3.82 & 3.82 & 3.82 & 3.82 \\
\hline Labor & 2.72 & 2.72 & 2.72 & 2.72 & 2.72 & 2.72 & 2.72 & 2.72 & 2.72 \\
\hline Depreciation & 43.19 & 43.19 & 43.19 & 43.19 & 43.19 & 43.19 & 43.19 & 43.19 & 43.19 \\
\hline Harvest and transport & 71.95 & 72.84 & 71.95 & 71.95 & 71.95 & - & - & - & 71.95 \\
\hline
\end{tabular}

GY: grain yield, LWG: live gain weight, NY: nitrogen yield, Wo: dual-purpose white oat ; Bo: black oat; V: vetch; DpW; dual-purpose wheat.

Dollar exchange rate on 15/12/2016: R\$ 0.2956 (Source: Central Bank of Brazil, 2016).

The statistical analysis consisted of analyzing the net return within each year (winter + summer) and the joint average of the years, in the periods from 2005/2006 to 2015/2016. In the joint analyzes, treatments with a fixed effect and the year effect were considered to be random. The parameters under study were subjected to the analysis of variance, by employing the SAS statistical program, version 9.4 (SAS Institute, 2017). The means were evaluated by the Duncan and sphericity tests at the level of $5 \%$.

\section{Results and Discussion}

The joint analysis of the data for net return per hectare, regarding the agricultural harvests from 2005/2006 to $2015 / 2016$, demonstrated that there is significance for the year effect and for the production system (Table 4). Similar results for the year effect were found by Santos et al. (2003) and De Mori et al. (2015) when working with grain production systems with crop + livestock integration, for five and ten years, respectively. Climatic conditions, which vary from one year to another, interfere in the yields of grain and dry matter from the studied species. There was no significance between the joint analyzes of the results from the annual net return per hectare for the interaction year $\mathrm{x}$ production systems.

For evaluations repeated over time, there was no significance for year or the interaction of year $\mathrm{x}$ production systems, by the sphericity test.

Winter and summer grain crops had their mean grain yield with a wide variation range (Table 2). Wheat from 2005 to 2015 , ranged from 2,027 to $2,570 \mathrm{~kg} \mathrm{ha}^{-1}$. Regarding maize, in the agricultural harvests from 2005-2006 to 2015-2015, the mean grain yield varied from 7,731 to $8,173 \mathrm{~kg} \mathrm{ha}^{-1}$, while in soybean it varied from 2,498 to $2,789 \mathrm{~kg} \mathrm{ha}^{-1}$. The species intended for dual-purpose (white oat, wheat and triticale) had a relatively low mean dry matter and grain yields, of 715 , 1,314 and $1,728 \mathrm{~kg} \mathrm{ha}^{-1}$, respectively.

Table 4. Analysis of mean net return, by hectare, from the production systems with integration crop-livestock, in the year (winter + summer) and in the mean of the agricultural harvests in the period from 2005/2006 to 2015/2016.

\begin{tabular}{|c|c|c|c|c|c|c|c|c|c|}
\hline \multirow{2}{*}{$\begin{array}{l}\text { Agricultural } \\
\text { harvests }\end{array}$} & \multicolumn{7}{|c|}{ Production systems with crop-livestock integration } & \multirow{2}{*}{$\begin{array}{l}\text { C.V. } \\
(\%) \\
\end{array}$} & \multirow{2}{*}{$\begin{array}{c}\text { F } \\
\text { Treat. }\end{array}$} \\
\hline & Syst I & Syst II & Syst III & Syst IV & Syst V & Syst VI & Mean & & \\
\hline \multicolumn{10}{|c|}{ Net return (U\$/ha) } \\
\hline 2005/06 & $43.13 \mathrm{~B}$ & $218.83 \mathrm{~A}$ & $9.43 \mathrm{~B}$ & $27.88 \mathrm{~B}$ & $-27.85 B$ & $47.03 \mathrm{~B}$ & $53.07 \mathrm{c}$ & 29 & $3.24 * *$ \\
\hline $2007 / 08$ & -195.66 & -136.15 & -275.71 & -168.64 & -299.83 & -266.87 & $-223.81 d$ & -64 & $1.78 \mathrm{~ns}$ \\
\hline $2008 / 09$ & $80.05 \mathrm{~A}$ & $170.44 \mathrm{~A}$ & $125.25 \mathrm{AB}$ & $57.17 A B$ & $-64.85 B$ & $106.65 \mathrm{~A}$ & $79.12 \mathrm{c}$ & 19 & $3.61 * *$ \\
\hline $2009 / 10$ & $73.10 \mathrm{~B}$ & $529.15 \mathrm{~A}$ & 271.75 B & 194.98 B & $136.01 \mathrm{~B}$ & $193.20 \mathrm{~B}$ & $233.03 b$ & 88 & $5.43^{* *}$ \\
\hline $2011 / 12$ & 58.50 & 164.15 & 40.67 & 35.32 & -27.46 & 164.86 & $72.67 c$ & 25 & $2.12 \mathrm{~ns}$ \\
\hline $2012 / 13$ & 287.41 & 407.13 & 203.79 & 97.16 & 75.76 & 216.76 & 214.67 b & 16 & $1.34 \mathrm{~ns}$ \\
\hline $2013 / 14$ & 235.21 & 344.29 & 409.23 & 187.38 & 303.05 & 295.36 & $295.75 a b$ & 10 & $0.55 \mathrm{~ns}$ \\
\hline $2014 / 15$ & 395.42 & 214.40 & 493.00 & 331.01 & 274.05 & 300.03 & 334.65 a & 65 & $1.78 \mathrm{~ns}$ \\
\hline $2015 / 16$ & 220.28 & 477.33 & 376.48 & 242.33 & 34.23 & 206.57 & $259.53 \mathrm{ab}$ & 13 & $2.40 \mathrm{~ns}$ \\
\hline Mean & $136.30 \mathrm{BC}$ & $278.25 \mathrm{~A}$ & 193.02 B & $111.14 \mathrm{CD}$ & 49.18 D & $125.31 \mathrm{C}$ & 148.92 & - & $12 * *$ \\
\hline
\end{tabular}

Syst: system. System I: wheat/soybean and vetch/maize; System II: wheat/soybean and black oat for pasture/maize; System III: wheat/soybean and black oat for pasture /soybean; System IV: wheat/soybean and pea/maize; System V: wheat/soybean, dual-purpose triticale /soybean and vetch/soybean; and System VI: wheat/soybean, dual-purpose white oat/ soybean and dual-purpose wheat /soybean. Treat.: treatment. ns: not significant; and **: significance level of $1 \%$. Means followed by the same letter, lowercase on the vertical and uppercase on the horizontal, do not show significant differences, at the level of $5 \%$ probability, by the Ducan test.

Dollar exchange rate on 15/12/2016: R\$ 0.2956 (Source: Central Bank of Brazil, 2016). 
Some winter grain (wheat) or dual-purpose (wheat and triticale) crops had higher total production costs than the summer grain crops (maize and soybean) (Table 3). On the other hand, cover crops and fertilization (pea and vetch), as well as pasture (black oat), had the lowest production costs. Based on these data, net return per hectare per year was determined for the species as well as the studied production systems.

In the annual analysis, there were significant differences in net return for the studied crops (data not shown). Of the eleven studied agricultural crops, maize had a higher net return than the other crops, both from winter and summer, in seven agricultural harvests (2005-2006, 2007-2008, 20082009, 2009-2010, 2010-2011, 2011-2012 and 2012-2013). However, in the 2013-2014 agricultural harvest, soybean had higher net return than the other crops studied, while in three agricultural harvests (2006-2007, 2014-2015 and 20152016) there was no difference between the crops. In most agricultural harvests, the net return from soybean, wheat and dual-purpose wheat were in an intermediate position while the dual-purpose triticale had the lowest net return among the evaluated grain crops.

In the joint mean of the agricultural harvests from 20052006 to 2015-2016, there was a significant difference in the net return associated with studied crops (data not shown). Considering the net return of the crops individually, maize stood out while soybean and dual-purpose wheat had intermediate values. The lowest revenues were from wheat, black oat, dualpurpose white oat, vetch, pea and dual-purpose triticale. This is an outlook from the perspective of each crop and must be cautiously evaluated, since it composes the target production systems of the following discussions.

Net return differed between the CLI systems adopted in four harvests evaluated (Table 4). In this case, system II stands out in the years of 2009/2010 (U\$ 529.15) and 2010/2011 (U\$ 497.64), with revenue higher than the other systems, which difference can be attributed to the rotation composition (maize, soybean, black oat and wheat). In this case, maize may have been fundamental in explaining this difference, since it had the highest grain yield in relation to production systems with legumes for ground cover and green manure (Santos et al., 2017). Moreover, maize grown after pea and vetch did not receive nitrogen top-dressing fertilization, which may have limited the grain yield of these systems, since they provided, on average, from 49 (pea) to 92 (vetch) kg of N per hectare, a lesser quantity than that required by maize.

Studies conducted in the Brazilian sub-tropics with grazing systems in the winter and soybean sowing in the summer, demonstrated that, from the viewpoint of the soil physical properties, there is no restriction for the development of subsequent crops, as long as there is no high-intensity grazing (Carvalho et al., 2010). This may have occurred sometimes in system II during the agricultural harvests, a fact that may prevent soil compaction, resulting in higher profitability per hectare. Hence, the crop-livestock integration allows the economic exploitation of the area throughout the year, which favors an increase in the supply of grains, meat and milk at a lower cost, due to the synergy between farming and pasture (Balbino et al., 2011; Reis et al., 2017).

When taking the means of the years into account, the highest net return was in system II, attaining U\$ 278.25 per hectare. This revenue is notably $562 \%$ higher than that of system $\mathrm{V}$, consisting of wheat, soybean, triticale and vetch. (Table 4). This result may be associated with the presence of maize in the rotation composition, where its high yield contributed to increasing net return. In this case, it is observed that, despite the lower sale value of maize (U\$ $5.85 \times 8,173$ $\mathrm{kg} \mathrm{ha}^{-1}$ and U\$1,183.81) in comparison with the soybean (U\$ $20.93 \times 2,719 \mathrm{~kg} \mathrm{ha}^{-1}$ and $\mathrm{U} \$ 948.32$ ) its higher grain mean yield per hectare compensated that said value (Table 2 ).

Zentner et al. (1990) and Fontaneli et al. (2000), studying grain production systems or annual winter pastures involving wheat, for five and six years respectively, found that the system composed of wheat/soybean and vetch/maize was more profitable than the one that had wheat/soybean, white oat/soybean and white oat/soybean and the one used only for grain production.

In studies conducted by Santos et al. (1999), in Guarapuava, PR, and by Ruedell (1995), in Cruz Alta, RS, with production systems involving the wheat crop, no significant differences were found between the means of net return. From what was observed in the present study and in the one from Fontaneli et al. (2000), livestock (intercropped pastures, for animal fattening) increased crop profitability (grain production).

The study conducted by Reis et al. (2018), with sensitivity analysis associated with profitability indicators and present net return, demonstrated that the crop-livestock-forest integration system (beef cattle, rubber and soybean) had superior results to soybean and second-crop maize crops and to the system based only on livestock (pasture with weaned calf breeding). According to the authors, the availability of these results through the system with crop-livestock-forest integration helps minimizing market risks due to diversification.

Therefore, as according to De Mori et al. (2015), the production systems may involve rotation of grain crops, land cover and pasture. Grain cultivation forms an important component of the agricultural activity and the basis of human and/or animal nutrition. Using soil cover crops, not directly generating income, has been efficient in controlling erosion, recycling nitrogen (Melero et al., 2013), in the provision and reduction of mineral fertilization and in promoting increased yield of subsequent crops. The addition of systems integrating agriculture and livestock activities has been growing in Brazil and, according to Costa et al. (2015), contributing to increasing nutrient cycling and improving soil quality.

In the comparison between systems I and II, considering the mean of the years, system II with black oat pasture preceding maize had a greater net return in relation to the system I, where vetch preceded maize (Table 4). In this same line, when comparing systems III and IV, it was found that system III, which had black oat pasture preceding soybean, attained a higher net return than system IV, with pea preceding maize. This was probably due to the greater animal weight gain in relation to the value of 
nitrogen incorporated into the soil by the legume species (Table 2). System VI was favored by the rotation composition, based on grains, even after grazing (double-purpose wheat and white oat) and thus attained a higher net return than the $V$ system, which had a component not used for grazing: vetch, whose revenue is associated with the $\mathrm{N}$ added to the soil.

In this study, the production systems were carried out with annual winter pastures (black oat) and dual-purpose species (white oat, wheat and triticale), subjected to cuttings or grazing, with subsequent grain harvesting. Cover cropping was also used as a way of adding $\mathrm{N}$ to the soil (pea and vetch). In systems I (wheat/soybean and vetch/maize), II (wheat/soybean and black oat/maize pasture) and IV (wheat/soybean and pea/ maize) the purpose was to cover the soil and incorporate $\mathrm{N}$ to it during winter, and then sow the maize at its optimal sowing time. In systems III (wheat/soybean and black oat/soybean pasture), V (wheat/soybean, vetch/soybean and dual-purpose triticale/soybean) and VI (wheat/soybean, dual-purpose white oat/soybean and dual-purpose wheat/soybean), the purpose was to cover the soil during winter, incorporate nitrogen in the case of vetch, and also to establish soybean, in its optimal growing period. However, system II was the highlight of this study because, after the black oat cultivation, maize received nitrogen top-dressing fertilization, increasing its yield and translating into a higher net return of this system. In the leguminous/maize systems, no nitrogen fertilizer was applied in succession, resulting in lesser maize yield and net return.

The importance of this research was associated with the study of production systems centered on grain and forage production in the crop-livestock integration model. Several crops for cover, grazing and grains were tested in combinations, and demonstrated using potential for the producer, within the scope of annual net return. Maize, which had its area gradually reduced in the State of Rio Grande do Sul, played an important role in the production system performance, and it was pointed out as fundamental in increasing the net return of the production system.

\section{Conclusions}

The crop-livestock integration system based on maize, succeeding black oat, stood out in relation to the others, as it had the highest annual net return.

The system with white oat and dual-purpose wheat preceding soybean had an intermediate and superior profitability when compared to the system with dual-purpose triticale and vetch preceding soybean.

\section{Literature Cited}

Balbino, L.C.; Cordeiro, L.A.M.; Porfírio-da-Silva, V.; Moraes, A. de; Martínez, G.B.; Alvarenga, R.C. Kichel, A.N.; Fontaneli, R.S.; Santos, H.P. dos; Franchini, J.C.; Galerani, P.R. Evolução tecnológica e arranjos produtivos de sistemas de integração lavoura-pecuáriafloresta no Brasil. Pesquisa Agropecuária Brasileira, v.46, n.10, p.ixii, 2011. https://doi.org/10.1590/S0100-204X2011001000001.
Banco Central do Brasil. Cotação. Dólar EUA. https://www.bcb.gov. br. 15 Dez. 2016.

Bonetti, J. A.; Anghinoni, I.; Gubiani, P. I.; Cecagno, D.; Moraes, M. T. de. Impact of a long-term crop-livestock system on the physical and hydraulic properties of an Oxisol. Soil and Tillage Research, v. 186, p. $280-291$, 2019. https://doi.org/10.1016/j. still.2018.11.003.

Carvalho, P.C. de F.; Anghinoni, I.; Moraes, A. de. Managing grazing animals to achieve nutrient Cycling and soil improvement in no-till integrated systems. Nutrient Cycling in Agroecosystems, v.88, n.2, p.259-273, 2010. https://doi.org/10.1007/s10705010-9360-x.

Comissão de Química e Fertilidade do Solo - RS/SC. Manual de calagem e adubação para os estados do Rio Grande do Sul e de Santa Catarina. 11.ed. Porto Alegre: Sociedade Brasileira de Ciência do Solo; Núcleo Regional Sul; Comissão de Química e Fertilidade do Solo - RS/SC, 2016. 376p.

Companhia Nacional de Abastecimentos - Conab. Portal de informações agropecuárias. Observatório agrícola. Custos de produção. Aveia branca, milho, soja sorgo e trigo. https:// portaldeinformacoes.conab.gov.br/index.php/precosminimos/precos-minimos-dashboard. 04 Nov. 2016.

Costa, N.R.; Andreotti, M.; Lopes, K.S.M.; Yokobatake, K.L.; Ferreira, J.P.; Pariz, C.M.; Bonini, C. dos S.B.; Longhini, V.Z. Atributos do solo e acúmulo de carbono na integração lavoura-pecuária em sistema plantio direto. Revista Brasileira de Ciência do Solo, v.39, n.3, p.852-863, 2015. https://doi.org/10.1590/01000683 rbcs20140269.

De Mori, C.; Santos, H.P. dos; Fontaneli, R.S.; Lampert, E.A. Análise econômica de sistemas de produção, mistos: grãos, cultura de cobertura e pecuária, 2003-2012. In: Reunião da Comissão Brasileira de Pesquisa de Trigo e Triticale, 8.; Seminário Técnico de Trigo, 9., 2014, Canela; Reunião da Comissão Brasileira de Pesquisa de Trigo e Triticale, 9.; Seminário Técnico de Trigo, 10., 2015, Passo Fundo. Anais... Passo Fundo: Biotrigo Genética; Embrapa Trigo, 2015. CD-Rom.

Fontaneli, R. S.; Ambrosi, I.; Santos, H. P. dos; Ignaczak, J. C.; Zoldan, S. M. Análise econômica de sistemas de produção de grãos com pastagens anuais de inverno, em sistema plantio direto. Pesquisa Agropecuária Brasileira, v. 35, n. 11, p. 2129-2137, 2000. https://doi.org/10.1590/S0100-204X2000001100002.

Fontaneli, R.S.; Meinerz, G.R.; Fontaneli, R.S.; Santos, H.P. dos; Biazus, V.; Fávero, D.; Rebechi, I. de A. A contribuição das forrageiras de inverno para a pecuária de leite. In: Vilela, D.; Ferreira, R. de P.; Fernandes, E.N.; Juntolli, F.V. (Eds.). Pecuária de leite no Brasil: cenários e avanços tecnológicos. Brasília: Embrapa, 2016. Cap. 5, p.239-253.

Fontaneli, R.S.; Varella, A.C.; Silva, J.L.S. da; Santos, H.P. dos. Desempenho das forrageiras subtropicais em sistema de integração lavoura-pecuária e de integração pecuária-floresta. In: Cordeiro, L.A.M.; Vilela, L.; Kluthcouski, J.; Maechão, R.L. (Eds.). Integração lavoura-pecuária-floresta: o produtor pergunta, a Embrapa responde. Brasília: Embrapa, 2015. Cap. 11, p.225-242. 
Knapp, A. K.; Smith, M. D.; Hobbie, S. E.; Collins, S. L.; Fahey, T. J.; Hansen, G.J. A.; Landis, D. A.; La Pierre, K. J.; Melillo, J. M.; Seastedt, T. R.; Shaver, R. G.; Webster, J. R. Past, present, and future roles of Long-Term Experiments in the LTER Network. BioScience, v. 62, n. 4, p. 377 - 389, 2012. https://doi.org/10.1525/bio.2012.62.4.9.

Kunde, R.J.; Lima, A.C.R. de; Silva, J.L.S. da; Valgas, R.A.; Pillon, C.N. Qualidade do solo em sistemas de integração lavoura-pecuária no Bioma-Pampa. Revista Brasileira de Ciências Agrárias, v.13, n.4, p.1-8, 2018. https://doi.org/10.5039/agraria.v13i4a5591.

Melero, M.M.; Gitti, D. de C.; Art, O.; Rodrigues, R.A.F. Coberturas vegetais e doses de nitrogênio em trigo sob sistema plantio direto. Pesquisa Agropecuária Tropical, v. 43, n.4, p.343-353, 2013. https://doi.org/10.1590/S1983-40632013000400001.

Reis, J.C. dos; Kamoi, M.Y.T.; Latorraca, D.; Michetti, M. Avaliação da viabilidade econômica-financeira para sistema de integração lavoura-pecuária em relação a um sistema de lavoura exclusiva em Mato Grosso, Brasil. In: Congresso da Sociedade Brasileira de Economia, Administração e Sociologia Rural, 55., 2017, Santa Maria. Anais... Brasília: SOBER, 2017. https://ainfo.cnptia. embrapa.br/digital/bitstream/item/172392/1/2017-cpamt-julioreis-viabilidade-economica-sistema-ilpf-vs-lavoura-exclusiva.pdf. 12 Dez. 2019.

Reis, J.C. dos; Kamoi, M.Y.T.; Michetti, M.; Wruck, F.J. Análise dos benefícios econômicos da diversificação da produção em sistemas de integração lavoura-pecuária-floresta. In: Congresso da Sociedade Brasileira de Economia, Administração e Sociologia Rural, 56., 2018, Campinas. Brasília: SOBER, 2018. Não paginado. http://ainfo.cnptia.embrapa.br/digital/bitstream/ item/200370/1/2019-cpamt-agrossilvipastoril-part-4-cap23-resultados-economicos-beneficio-diversidade-producaosistema-ilpf-p-303-310.pdf. 12 Dez. 2019.

Ruedell, J. Plantio direto na região de Cruz Alta. Cruz Alta: Fundacep Fecotrigo, 1995. $134 \mathrm{p}$.

Santos, H. P. dos; Ambrosi, I.; Ignaczak, J. C.; Wobeto, C. Análise econômica de sistemas de rotação de culturas para trigo, num período de dez anos, sob plantio direto. Pesquisa Agropecuária Brasileira, v. 34, n. 12, p. 2175-2183, 1999. https://doi. org/10.1590/S0100-204X1999001200002.
Santos, H. P. dos; Fontaneli, R. S.; Machado, J. R. de A.; Possebom, T.; Busatta, B. P. Avaliação de milho cultivado em três sistemas de produção com integração lavoura-pecuária sob sistema plantio direto. In: Reunião Técnica Anual do Milho, 62.; Reunião Técnica Anual do Sorgo, 45., 2017, Sertão. Anais... Sertão: Instituto Federal do Rio Grande do Sul; Sete Lagoas: Associação Brasileira de Milho e Sorgo, 2017. p. 5-8. http://ainfo.cnptia.embrapa.br/digital/bitstream/ item/163302/1/ID44104-2017RTAM1365.pdf. 10 Dez. 2019.

Santos, H.G. dos; Jacomine, P.K.T.; Anjos, L.H.C. dos; Oliveira, V.A. de; Lumbreras, J.F.; Coelho, M.R.; Almeida, J.A. de; Araujo Filho, J. C. de; Oliveira, J.B. de.; Cunha, T. J. F. Sistema brasileiro de classificação de solos. 5.ed. Brasília: Embrapa, 2018. 356 p.

Santos, H.P. dos.; Fontaneli, R.S.; Spera, S.T. Avaliação de sistemas de rotação de culturas na análise econômica e de risco, nas décadas de 1980 a 2010. In: Santos, H.P. dos; Fontaneli, R.S.; Spera, S.T.; Pires, J.L.F.; Santi, A. (Eds.). Sistemas de produção para cereais de inverno: 30 anos de estudos. Brasília, DF: Embrapa, 2015a. Cap. 8, p.263-314.

Santos, H.P. dos; Fontaneli, R.S.; Ambrosi, I. Análise econômica de culturas de inverno e de verão em sistemas mistos, sob plantio direto. Pesquisa Agropecuária Gaúcha, v.9, n.1-2, p. 121-128, 2003. http://revistapag.agricultura.rs.gov.br/ojs/index.php/ revistapag/article/view/511. 18 Dez. 2019.

Santos, H.P. dos; Fontaneli, R.S.; Castro, R.L. de; Verdi, A.C.; Vargas, A.M.; BIAZUS, V. Avaliação de trigo para grãos e duplo propósito, sob plantio direto. Revista Brasileira de Ciências Agrárias, v.10, n.1, p.43-48, 2015b. https://doi.org/10.5039/agraria.v10i1a4567.

SAS Institute. SAS system for Microsoft Windows Version 9.4. Cary: SAS Institute, 2017.

Vilela, L.; Martha Junior, G.B.; Macedo, M.C.M.; Marchão, R.L.; Guimarães Junior, R.; Pulrolnik, K.; Maciel, G.A. Sistemas de integração lavoura-pecuária na região do Cerrado. Pesquisa Agropecuária Brasileira, v.46, n.10, p.1127-1138, 2011. https:// doi.org/10.1590/S0100-204X2011001000003.

Zentner, R. P.; Selles, F.; Santos, H. P. dos; Ambrosi, I. Effect of crop rotations on yields, soil characteristics, and economic returns in Southern Brazil. In: International Workshop on Conservation Tillage Systems, 1990, Passo Fundo. Passo Fundo: CIDA; EmbrapaCNPT, 1990. p. 96-116. 